\title{
Characterization of Potential Plant Growth Promoting Rhizobacteria Isolated from Maize (Zea mays L.) in Central and Northern Benin (West Africa)
}

\author{
Nadège A. Agbodjato, ${ }^{1}$ Pacôme A. Noumavo, ${ }^{1}$ Farid Baba-Moussa, ${ }^{2}$ \\ Hafiz A. Salami, ${ }^{1}$ Haziz Sina, ${ }^{1}$ Alphonse Sèzan, ${ }^{3}$ Honoré Bankolé, ${ }^{4}$ \\ Adolphe Adjanohoun, ${ }^{5}$ and Lamine Baba-Moussa ${ }^{1}$ \\ ${ }^{1}$ Laboratoire de Biologie et de Typage Moléculaire en Microbiologie, Département de Biochimie et de Biologie Cellulaire, \\ Faculté des Sciences et Techniques, Université d'Abomey-Calavi, 05 BP 1604 Cotonou, Benin \\ ${ }^{2}$ Laboratoire de Microbiologie et de Technologie Alimentaire, Faculté des Sciences et Techniques, Université d'Abomey-Calavi, \\ 04 BP 1107 Cotonou, Benin \\ ${ }^{3}$ Laboratoire de Biomembrane et de Signalisation Cellulaire, Faculté des Sciences et Techniques, Université d'Abomey-Calavi, \\ 01 BP526 Abomey-Calavi, Benin \\ ${ }^{4}$ Section Hygiène des Eaux et Aliments, Laboratoire National de Santé Publique, 01 BP 418 Cotonou, Benin \\ ${ }^{5}$ Centre de Recherches Agricoles Sud, Institut National des Recherches Agricoles du Bénin, BP 03 Attogon, Benin
}

Correspondence should be addressed to Lamine Baba-Moussa; laminesaid@yahoo.fr

Received 5 April 2015; Accepted 21 July 2015

Academic Editor: Marco Trevisan

Copyright (C) 2015 Nadège A. Agbodjato et al. This is an open access article distributed under the Creative Commons Attribution License, which permits unrestricted use, distribution, and reproduction in any medium, provided the original work is properly cited.

\begin{abstract}
Our study aims to characterize Plant Growth Promoting Rhizobacteria (PGPR) isolated from maize roots in five agroecological zones of central and northern Benin. Sixty samples were collected at the rate of four samples per village and three villages per agroecological zone. Rhizobacteria strains were isolated from these samples and biochemically characterized. These strains were analyzed for some of their PGPR traits like ammonia production and hydrogen cyanide following conventional methods. Microbiological investigation of these samples has shown that maize rhizospheres in central and northern Benin contain a high diversity of microorganisms. A total of nine species of maize Plant Growth Promoting Rhizobacteria were identified. Those PGPR include five Bacillus species (B. polymyxa, B. pantothenticus, B. anthracis, B. thuringiensis, and B. circulans), three Pseudomonas species (P. cichorii, P. putida, and P. syringae), and Serratia marcescens. The microbial diversity does not depend on the soil types. The microbial density, generally high, varies according to both soil types and agroecological zones. All Serratia strains (100\%) have produced ammonia, whereas $80 \%$ of Bacillus and $77.77 \%$ of Pseudomonas produced this metabolite. The hydrogen cyanide was produced by all isolates (100\%) independent of their genus. These results suggest the possibility to use these rhizobacteria as biological fertilizers to increase maize production.
\end{abstract}

\section{Introduction}

The first aim of agriculture was to ensure survival by producing the necessary for feeding. It was subsistence farming. But nowadays, due to continued and worrying growth of world population, this primary objective of agriculture changed completely. Indeed, the world population is estimated around 7 billion people and may reach 8 billion by 2020 [1]. So, it is urgent to considerably increase the agricultural production to reply to the strong food demand to reduce the risk of malnutrition and the increasing of poverty.

Therefore, the new cereal varieties of high yield were developed. In addition, agrochemical products such as chemical fertilizers, herbicides, fungicides, and insecticides were currently improperly and excessively used in order to increase crop yield. The direct consequence of these agrochemical 
products use is the environment pollution through ground water and crop products contamination by heavy metals that are contained in these agricultural inputs. These heavy metals are known to be a public health problems because, transferred to humans, they are involved in the cancer occurrence [2]. Apart from medical damages, other consequences in agricultural area such as natural ecological nutrient cycling interruption and soil biological communities destruction are frequently reported [3]. Regarding the damages caused by the excessive use of agrochemical products, other research paths are explored worldwide. Among the explored paths, the use of microorganism currently called Plant Growth Promoting Rhizobacteria (PGPR) is in pole position.

Indeed, the PGPR is a group of bacteria capable of colonizing actively plant roots system and improving their growth and yield [4]. The expression "PGPR" was firstly proposed by Kloepper et al. [5] and was used especially for the fluorescent Pseudomonas involved in biological control of pathogens and the improvement of plant growth. Later, Kapulnik et al. [6] extended this expression to rhizobacteria capable of promoting directly the plant growth. Nowadays, this expression is used to refer to all bacteria living in the rhizosphere (around roots), improving plant growth by one or several mechanisms [7]. A large range of species belonging to the genus Pseudomonas, Azospirillum, Azotobacter, Klebsiella, Enterobacter, Alcaligenes, Arthrobacter, Burkholderia, Bacillus, and Serratia were reported to be PGPR [8].

Yazdani et al. [9] asserted that the PGPR use can reduce the application of phosphorus to $50 \%$ without affecting the maize (Zea mays L.) seed yield. Several authors reported the increase of maize yield [10,11], Tea [12], soybeans [13], alfalfa [14], wheat [15], and onion [16] simply by PGPR inoculation.

In this context, the aim of our study was to isolate and identify the potential PGPR from maize (most cultivated and consumed cereal in Benin) rhizosphere in the central and northern Benin. The medium-dated objective of this study is to propose for farmers the biological fertilizers based on native PGPR for increasing maize production.

\section{Materials and Methods}

2.1. Geographical Characterization of Study Area. This study was carried in five agroecological zones (I, II, III, IV, and V) located in the central and northern Benin, West Africa (Figure 1). Indeed, Benin is localized in West Africa (south of Sahara), in the tropical zone between Equator and Tropic of Cancer, precisely between the parallel $6^{\circ} 30^{\prime}$ and $12^{\circ} 30^{\prime}$ of north latitude and meridians $1^{\circ}$ and $30^{\circ} 40^{\prime}$ of east longitude.

2.2. Collection of Rhizospheric Samples. Three (3) villages were selected by agroecological zone and four fields were chosen in each village. Three maize plants distanced at least 10 meters were dug up in each field. Their roots were cut with soil adheres and mixed in a bucket. Three hundred grams of this mixture was packed in a sterile stomacher bag and labeled correctly to form the sample of the field. A total of 60 samples were collected and immediately transported at $4^{\circ} \mathrm{C}$ to the laboratory for further analysis. Once they are at the laboratory, the microbiological screening was immediately realized or samples were kept at $4^{\circ} \mathrm{C}$ until screening.

Several other parameters (climate, soil type, annual pluviometry, and other crops grown except for maize) of the sampling sites were collected during the sampling.

2.3. Isolation of Rhizobacteria. According to Speck [17] method, $10 \mathrm{~g}$ of each sample was mixed into Erlenmeyer flask containing $90 \mathrm{~mL}$ of tryptone salt. The mixture was vigorously shaken for about $30 \mathrm{~s}$ to obtain $10^{-1}$ dilution. The previous dilution $(1 \mathrm{~mL})$ was transferred into $9 \mathrm{~mL}$ of tryptone salt to obtain $10^{-2}$ dilution. This operation was repeated until obtaining $10^{-8}$ dilution. Each dilution $(0.1 \mathrm{~mL})$ was streaked on different specific isolation media. The aerobic mesophilic flora was enumerated on Plate Count Agar as recommended by the French standard V08-051. Bacillus sp. and Serratia sp. were isolated on nutrient agar after incubation at $37^{\circ} \mathrm{C}$ for $24 \mathrm{~h}$ and $30^{\circ} \mathrm{C}$ for $48 \mathrm{~h}$, respectively $[18,19]$. Pseudomonas sp. was isolated on King A and King B agar after incubation at $30^{\circ} \mathrm{C}$ for $72 \mathrm{~h}$ [20].

2.4. Identification of Rhizobacteria. The identification of isolated rhizobacteria consisted firstly in macroscopic (colony morphology, pigmentation, etc.) and microscopic (gram reaction, mobility, cell shape, spores position, etc.) observations. This first identification was followed by several biochemical and enzymatic tests. The performed tests are production of oxidase, catalase, indole, urease and hydrogen sulfide, respiratory type, acid and gas production on glucose agar, citrate and nitrate utilization, hydrolysis of starch, casein, mannitol, gelatin and lecithin, fermentation of glucose and lactose, growth on MacConkey and Cetrimide agar; Voges-Proskaur test, growth at $42,45,55$, and $65^{\circ} \mathrm{C}$, and fluorescence at $360^{\circ} \mathrm{C}[18,21-23]$.

\subsection{Plant Growth Promoting Properties}

2.5.1. Hydrogen Cyanide Production. All isolated rhizobacteria were screened for hydrogen cyanide production following the method described by Lorck [24]. Each rhizobacterium was streaked on nutrient agar medium added with glycine $(4.4 \mathrm{~g} / \mathrm{L})$. The agar was covered with a Whatman number 1 filter paper previously soaked in a specific solution $(0.5 \%$ picric acid and $2 \%$ sodium carbonate $\mathrm{w} / \mathrm{v}$ ). Plates were sealed with parafilm paper and incubated at $36 \pm 2^{\circ} \mathrm{C}$ for 4 days. The appearance of orange or red color indicates the production of hydrogen cyanide.

2.5.2. Ammonia Production. To research the production of ammonia, each identified rhizobacteria strain was grown in peptone broth $(10 \mathrm{~mL})$ and incubated at $36 \pm 2^{\circ} \mathrm{C}$ for 48 to $72 \mathrm{~h}$. After incubation, $0.5 \mathrm{~mL}$ of Nessler's reagent was added to bacterial suspension. The development of brown to yellow color indicated ammonia production [25].

2.6. Statistical Analysis. Microsoft Office Excel 2007 had been used to create data base. The different parameters evaluated were submitted to Analysis of Variance (ANOVA) 


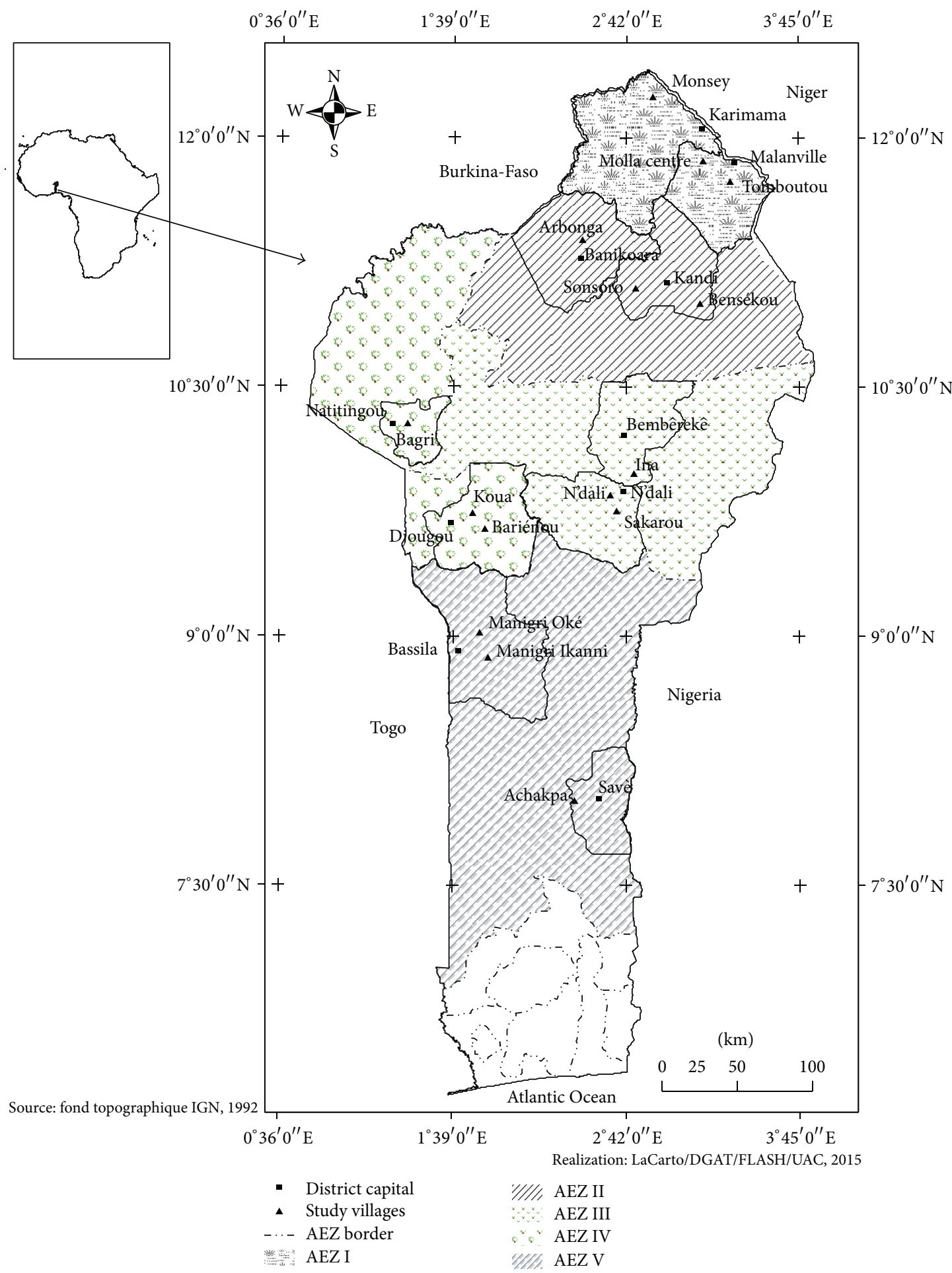

Figure 1: Agroecological zones surveyed. AEZ: agroecological zone; AEZ I = Far North Benin; AEZ II = Cotton zone of North Benin; AEZ III = food-producing zone of South Benin; AEZ IV = West Atacora zone; AEZ V = Cotton zone of Central Benin; AEZ IV = Bar Land zone.

at probability level of $5 \%$, following a mean separation (Student-Newman-Keuls test), by Statistical Analysis System (SAS) software Version 8.1. In this model, soil types and agroecological zones were considered as a fixed factor while replicates were considered as a random factor.

\section{Results}

3.1. Agroecological Characteristics of the Villages Surveyed. Table 1 shows agroecological characteristics of villages surveyed by agroecological zone. The Sudanese climate with 
TABLE 1: Agroecological characteristics of villages surveyed.

\begin{tabular}{|c|c|c|c|c|c|}
\hline $\begin{array}{l}\text { Agroecological } \\
\text { zone }\end{array}$ & Climate & $\begin{array}{l}\text { Annual } \\
\text { pluviometry }(\mathrm{mm})\end{array}$ & Village & Type of soil & Other crops grown \\
\hline $\begin{array}{l}\text { I : } \\
\text { Far North Benin }\end{array}$ & $\begin{array}{l}\text { Sudano-Sahelian } \\
\text { with one rainy } \\
\text { season }\end{array}$ & 700 to $900 /$ years & $\begin{array}{l}\text { Tomboutou } \\
\text { Monsey } \\
\text { Molla centre }\end{array}$ & $\begin{array}{l}\text { Washing and No Concretion } \\
\text { Tropical Ferruginous Soil } \\
\text { Washing and Hydromorphic } \\
\text { Tropical Ferruginous Soil }\end{array}$ & Rice, sorghum, small millet \\
\hline $\begin{array}{l}\text { II : } \\
\text { Cotton zone of } \\
\text { North Benin }\end{array}$ & $\begin{array}{l}\text { Sudanese with one } \\
\text { rainy season }\end{array}$ & 800 to $900 /$ years & $\begin{array}{l}\text { Bensékou } \\
\text { Sonsoro } \\
\text { Arbonga }\end{array}$ & $\begin{array}{l}\text { Washing and Idurate Tropical } \\
\text { Ferruginous Soil } \\
\text { Washing and Hydromorphic } \\
\text { Tropical Ferruginous Soil }\end{array}$ & Millet \\
\hline $\begin{array}{l}\text { III: } \\
\text { food-producing } \\
\text { zone of } \\
\text { South Benin }\end{array}$ & $\begin{array}{l}\text { Sudanese with one } \\
\text { rainy season }\end{array}$ & 900 to 1300 /years & $\begin{array}{l}\text { Ina } \\
\text { N'dali } \\
\text { Sakarou }\end{array}$ & $\begin{array}{l}\text { Washing and Concretion } \\
\text { Tropical Ferruginous Soil }\end{array}$ & $\begin{array}{l}\text { Sorghum, cotton, bean, } \\
\text { cassava }\end{array}$ \\
\hline $\begin{array}{l}\text { IV: } \\
\text { West } \\
\text { Atacora zone }\end{array}$ & $\begin{array}{l}\text { Sudanese with one } \\
\text { rainy season }\end{array}$ & 800 to $1300 /$ years & $\begin{array}{l}\text { Bariénou } \\
\text { Koua } \\
\text { Bagri }\end{array}$ & $\begin{array}{l}\text { Few Washing Tropical } \\
\text { Ferruginous Soil } \\
\text { Few Developed Soil }\end{array}$ & $\begin{array}{l}\text { Sorghum, bean, bambara } \\
\text { groundnut, cassava, } \\
\text { groundnut, yam }\end{array}$ \\
\hline $\begin{array}{l}\text { V: } \\
\text { Cotton Zone of } \\
\text { Central Benin }\end{array}$ & $\begin{array}{l}\text { Sudano-Guinean } \\
\text { with two rainy } \\
\text { seasons }\end{array}$ & 1100 to $1400 /$ years & $\begin{array}{l}\text { Achakpa } \\
\text { Manigri Oké } \\
\text { Manigri Ikanni }\end{array}$ & $\begin{array}{l}\text { Impoverished Tropical } \\
\text { Ferruginous Soil } \\
\text { Washing and No Concretion } \\
\text { Tropical Ferruginous Soil }\end{array}$ & Yam, cassava, pimento \\
\hline
\end{tabular}

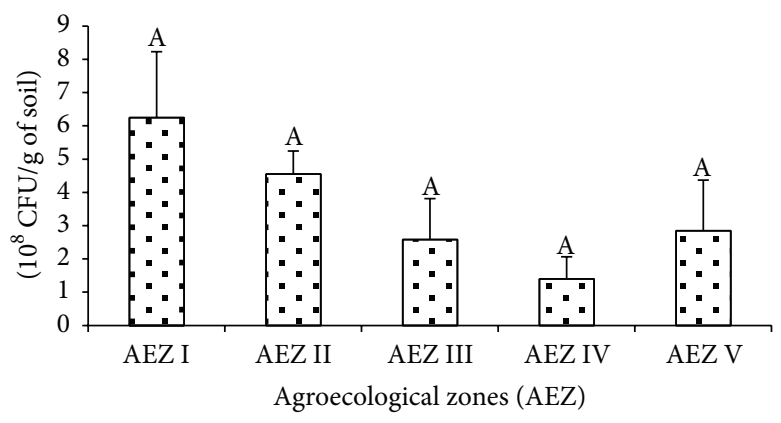

(a)

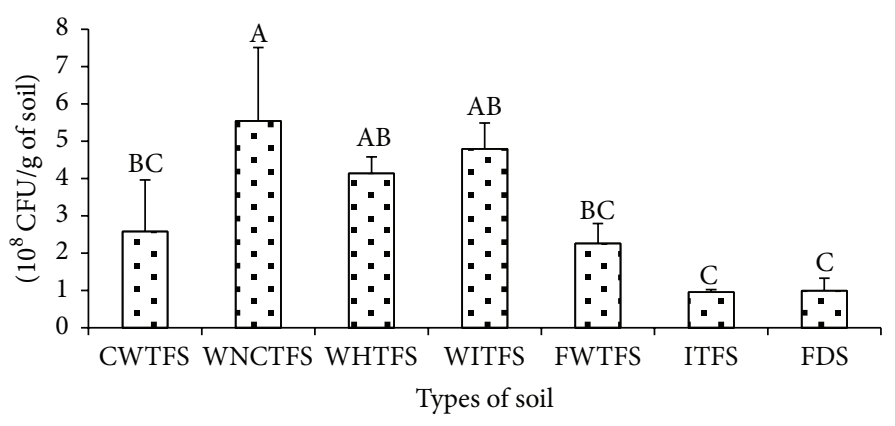

(b)

FIgure 2: Distribution of aerobic mesophilic flora according to (a) AEZ and (b) type of soil. WCTFS: Washing and Concretion Tropical Ferruginous Soil; WNCTFS: Washing and No Concretion Tropical Ferruginous Soil; WHTFS: Washing and Hydromorphic Tropical Ferruginous Soil; WITFS: Washing and Idurate Tropical Ferruginous Soil; FWTFS: Few Washing Tropical Ferruginous Soil; ITFS: Impoverished Tropical Ferruginous Soil; FDS: Few Developed Soil. The means with different letters are significantly different with probability level of 5\% according to Student-Newman-Keuls test.

one rainy season predominates in the five agroecological zones. Annual pluviometry varies from $700 \mathrm{~mm} /$ year (zone I) to $1400 \mathrm{~mm} /$ year (zone V). Pluviometry increases when we come from northern to southern Benin. The study area is characterized by 7 different types of soil. These soil types are the Washing and Concretion Tropical Ferruginous Soil (WCTFS), the Washing and No Concretion Tropical Ferruginous Soil (WNCTFS), the Washing and Hydromorphic Tropical Ferruginous Soil (WHTFS), the Washing and Idurate Tropical Ferruginous Soil (WITFS), the Few Washing Tropical Ferruginous Soil (FWTFS), the Impoverished Tropical Ferruginous Soil (ITFS), and the Few Developed Soil (FDS). Except for zone III, all the other agroecological zones contain at least two different types of soil. Several other crops were grown by farmers apart from the maize.

3.2. Density of Mesophilic Microflora. The agroecological zones and soil types investigated in this study present a varied microbial density. The rhizosphere of agroecological zone I contains mesophilic microflora $\left(6.25 \times 10^{8} \mathrm{CFU} / \mathrm{g}\right.$ of soil $)$ clearly abundant compared to the other agroecological zones (Figure 2(a)). The zone IV is the least loaded in mesophilic microflora $\left(1.40 \times 10^{8} \mathrm{CFU} / \mathrm{g}\right.$ of soil). Our data display that the Washing and No Concretion Tropical Ferruginous Soil (WNCTFS) contains the highest mesophilic microbial 


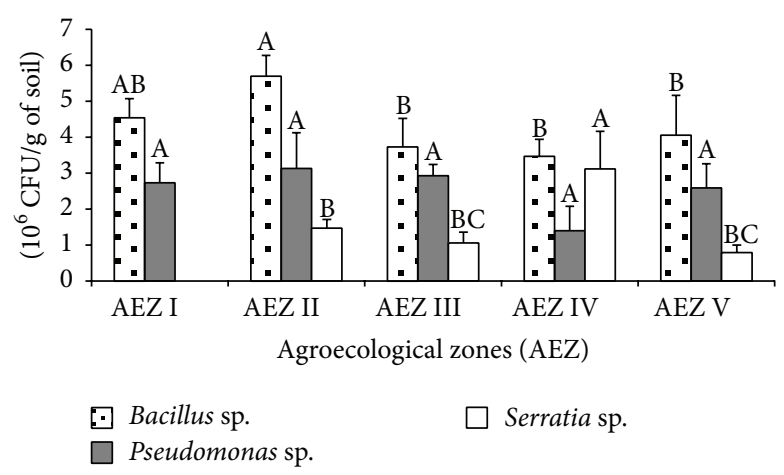

(a)

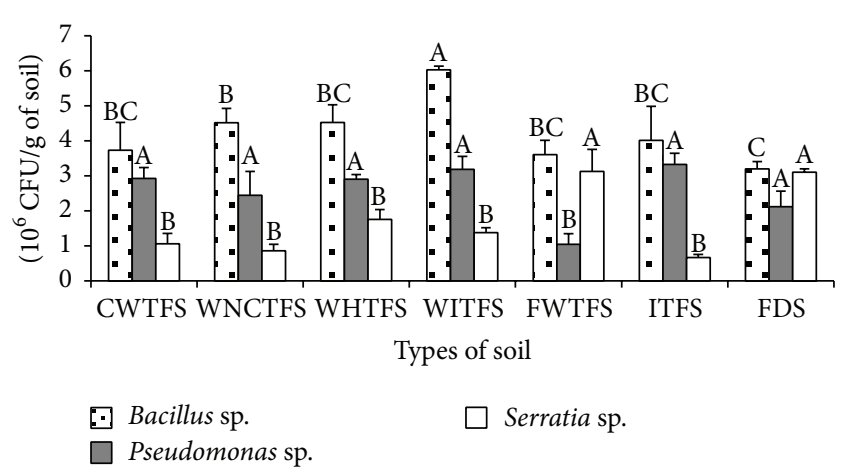

(b)

FIGURE 3: Distribution of rhizobacteria density according to (a) AEZ and (b) type of soil. WCTFS: Washing and Concretion Tropical Ferruginous Soil; WNCTFS: Washing and No Concretion Tropical Ferruginous Soil; WHTFS: Washing and Hydromorphic Tropical Ferruginous Soil; WITFS: Washing and Idurate Tropical Ferruginous Soil; FWTFS: Few Washing Tropical Ferruginous Soil; ITFS: Impoverished Tropical Ferruginous Soil; FDS: Few Developed Soil. The means with different letters are significantly different with probability level of $5 \%$ according to Student-Newman-Keuls test.

population $\left(5.54 \times 10^{8} \mathrm{CFU} / \mathrm{g}\right.$ of soil). The lowest mesophilic microflora charge was recorded with the Impoverished Tropical Ferruginous Soil (ITFS, $0.99 \times 10^{8} \mathrm{CFU} / \mathrm{g}$ of soil) and Few Developed Soil (FDS, $0.95 \times 10^{8} \mathrm{CFU} / \mathrm{g}$ of soil) (Figure 2(b)).

3.3. Density of Rhizobacteria Isolated. The density of isolated rhizobacteria according to agroecological zone and soil type is shown in Figure 3. The rhizospheres of agroecological zone II contain the highest density of Bacillus sp. $\left(5.70 \times 10^{6} \mathrm{CFU} / \mathrm{g}\right.$ of soil) and Pseudomonas sp. $\left(3.13 \times 10^{6} \mathrm{CFU} / \mathrm{g}\right.$ of soil). On the contrary, samples of the agroecological zone IV contain the lowest population of Bacillus sp. $\left(3.47 \times 10^{6} \mathrm{CFU} / \mathrm{g}\right.$ of soil $)$ and Pseudomonas sp. $\left(1.40 \times 10^{6} \mathrm{CFU} / \mathrm{g}\right.$ of soil). Serratia sp. is not found in rhizosphere of agroecological zone I (Figure 3(a)), but it is abundant in rhizosphere of agroecological zone IV $\left(3.12 \times 10^{6} \mathrm{CFU} / \mathrm{g}\right.$ of soil).

The density of rhizobacteria strains varies also from a soil type to another (Figure 3(b)). The Washing and Idurate Tropical Ferruginous Soil (WITFS) contains the largest population of Bacillus sp. $\left(6.03 \times 10^{6} \mathrm{CFU} / \mathrm{g}\right.$ of soil $)$ whereas the Few Developed Soil (FDS) contains the least population of Bacillus spp. $\left(3.2 \times 10^{6} \mathrm{CFU} / \mathrm{g}\right.$ of soil). Impoverished Tropical Ferruginous Soil (ITFS) and Few Washing Tropical Ferruginous Soil (FWTFS) contain, respectively, the large populations of Pseudomonas sp. and Serratia sp. In general, the density of Bacillus sp. is higher than Pseudomonas sp. and Serratia sp. Serratia sp. is the least abundant in the majority of soils.

3.4. Rhizobacteria Species Identified. Microbial investigation of samples collected from the 5 agroecological zones showed the presence of several rhizobacterial species. Five Bacillus species (B. polymyxa, B. pantothenticus, B. anthracis, B. thuringiensis, and $B$. circulans), 3 Pseudomonas species ( $P$. cichorii, $P$ putida, and P. syringae), and Serratia marcescens were identified. The morphological and biochemical characteristics of these rhizobacteria are shown in Table 2.
3.5. Ammonia and Hydrogen Cyanide Production by Rhizobacteria. The production of ammonia $\left(\mathrm{NH}_{3}\right)$ and hydrogen cyanide $(\mathrm{HCN})$ by rhizobacteria isolated from soil samples collected in the northern and central Benin is shown in Table 3. Our data suggested that all the rhizobacteria strains produce hydrogen cyanide. Concerning the production of ammonia, it was observed that all Serratia strains produce it against $80 \%$ of Bacillus sp. and $77.77 \%$ of Pseudomonas sp. (Table 3).

\section{Discussion}

Several studies have reported the benefit of seeds inoculation by Plant Growth Promoting Rhizobacteria. This growth promoting effect is influenced by biotic and abiotic factors including bacterial species and the soil types. It is in this context that this prospective study was realized in prelude of the promotion of microbial biofertilizers based on native rhizobacteria. The agroecological characteristics of sites samples collected were presented in Table 1. Each agroecological zone contains at least two soil types. The soil types encountered are Washing and Concretion Tropical Ferruginous Soil, Washing and No Concretion Tropical Ferruginous Soil, Washing and Hydromorphic Tropical Ferruginous Soil, Washing and Idurate Tropical Ferruginous Soil, Few Washing Tropical Ferruginous Soil, Impoverished Tropical Ferruginous Soil, and Few Developed Soil. This result is different to those obtained in the southern Benin by Adjanohoun et al. [26]. Indeed, our result reflects the large soils diversity in Benin as Adjanohoun et al. [26] reported other types of soil such as Vertisols, Degraded Bar Land, and No Degraded Bar Land.

Apart from maize, many other crops are growing in different villages surveyed in this study. These crops are rice, sorghum, small millet, millet, cotton, bean, cowpea, cassava, bambara groundnut, yam, and pimento. In southern Benin, except maize, Adjanohoun et al. [26] had identified cotton, groundnut, sweet potato, cowpea, and cassava. These cultures were mostly found in northern and central Benin. Firstly, 
TABLE 2: Morphological and biochemical characteristics of rhizobacteria isolated from samples collected in the central and northern Benin.

\begin{tabular}{|c|c|c|c|c|c|c|c|c|c|}
\hline \multirow{2}{*}{ Test } & \multicolumn{5}{|c|}{ Bacillus } & \multicolumn{3}{|c|}{ Pseudomonas } & \multirow{2}{*}{$\begin{array}{c}\text { Serratia } \\
\text { marcescens }\end{array}$} \\
\hline & polymyxa & pantothenticus & anthracis & thuringiensis & circulans & cichorii & putida & syringae & \\
\hline Bacteria shape & Rod & Rod & Rod & Rod & Rod & Rod & Rod & Rod & Rod \\
\hline Gram reaction & + & + & + & + & + & - & - & - & - \\
\hline $\begin{array}{l}\text { Catalase } \\
\text { production }\end{array}$ & + & + & + & + & + & + & + & + & + \\
\hline Spore position & Central & Terminal & Central & Central & Central & nd & nd & nd & nd \\
\hline $\begin{array}{l}\text { Growth on } \\
\text { anaerobic } \\
\text { condition }\end{array}$ & + & + & + & + & + & nd & nd & nd & nd \\
\hline $\begin{array}{l}\text { Acid from } \\
\text { glucose }\end{array}$ & + & + & + & + & + & nd & nd & nd & nd \\
\hline $\begin{array}{l}\text { Gas from } \\
\text { glucose }\end{array}$ & + & - & - & - & - & nd & nd & nd & nd \\
\hline Mobility & + & + & - & + & - & + & + & + & + \\
\hline $\begin{array}{l}\text { Delay on } \\
\text { glucose }\end{array}$ & - & - & - & - & - & nd & nd & nd & nd \\
\hline $\begin{array}{l}\text { Voges- } \\
\text { Proskauer }\end{array}$ & + & - & + & + & - & nd & nd & nd & nd \\
\hline $\begin{array}{l}\text { Indole } \\
\text { production }\end{array}$ & - & - & - & - & - & nd & nd & nd & - \\
\hline $\begin{array}{l}\text { Citrate } \\
\text { utilization }\end{array}$ & - & - & - & - & - & nd & nd & nd & + \\
\hline $\begin{array}{l}\text { Mannitol } \\
\text { utilization }\end{array}$ & nd & nd & nd & nd & nd & + & + & + & + \\
\hline $\begin{array}{l}\text { Starch } \\
\text { hydrolysis }\end{array}$ & + & + & + & + & + & nd & nd & nd & nd \\
\hline $\begin{array}{l}\text { Casein } \\
\text { hydrolysis }\end{array}$ & + & + & + & + & - & nd & nd & nd & + \\
\hline $\begin{array}{l}\text { Gelatin } \\
\text { liquefaction }\end{array}$ & + & + & + & + & + & nd & nd & nd & + \\
\hline $\begin{array}{l}\text { Lecithin } \\
\text { hydrolysis }\end{array}$ & + & - & + & + & - & + & - & - & nd \\
\hline $\begin{array}{l}\text { Urease } \\
\text { hydrolysis }\end{array}$ & - & - & - & - & - & nd & nd & nd & - \\
\hline DNAse activity & nd & nd & nd & nd & nd & nd & nd & nd & + \\
\hline $\begin{array}{l}\text { Nitrate } \\
\text { reduction }\end{array}$ & + & + & + & + & - & nd & nd & nd & nd \\
\hline Growth at $45^{\circ} \mathrm{C}$ & + & + & - & + & + & nd & nd & nd & nd \\
\hline Growth at $55^{\circ} \mathrm{C}$ & - & - & - & - & - & nd & nd & nd & nd \\
\hline Growth at $65^{\circ} \mathrm{C}$ & - & - & - & - & - & nd & nd & nd & nd \\
\hline $\begin{array}{l}\text { Fluorescence à } \\
360 \mathrm{~nm}\end{array}$ & nd & nd & nd & nd & nd & + & + & + & nd \\
\hline $\begin{array}{l}\text { Colony on } \\
\text { nutrient agar }\end{array}$ & nd & nd & nd & nd & nd & Whitish-Shiny & Whit-Shiny & Whitish-Shiny & nd \\
\hline $\begin{array}{l}\text { Oxidase } \\
\text { production }\end{array}$ & nd & nd & nd & nd & nd & + & + & - & nd \\
\hline $\begin{array}{l}\text { Glucose } \\
\text { fermentation }\end{array}$ & nd & nd & nd & nd & nd & - & - & - & + \\
\hline $\begin{array}{l}\text { Lactose } \\
\text { fermentation }\end{array}$ & nd & nd & nd & nd & nd & - & - & - & - \\
\hline Gas production & nd & nd & nd & nd & nd & - & - & - & - \\
\hline $\mathrm{H}_{2} \mathrm{~S}$ production & nd & nd & nd & nd & nd & - & - & - & - \\
\hline
\end{tabular}


TABLE 2: Continued.

\begin{tabular}{|c|c|c|c|c|c|c|c|c|c|}
\hline \multirow{2}{*}{ Test } & \multicolumn{5}{|c|}{ Bacillus } & \multicolumn{3}{|c|}{ Pseudomonas } & \multirow{2}{*}{$\begin{array}{c}\text { Serratia } \\
\text { marcescens }\end{array}$} \\
\hline & polymyxa & pantothenticus & anthracis & thuringiensis & circulans & cichorii & putida & syringae & \\
\hline $\begin{array}{l}\text { Growth on } \\
\text { Cétrimide } \\
\left(37^{\circ} \mathrm{C}\right)\end{array}$ & nd & nd & nd & nd & nd & - & + & + & nd \\
\hline $\begin{array}{l}\text { Growth on } \\
\text { Cétrimide } \\
\left(42^{\circ} \mathrm{C}\right)\end{array}$ & nd & nd & nd & nd & nd & - & + & - & nd \\
\hline $\begin{array}{l}\text { Growth on } \\
\text { MacConkey }\end{array}$ & nd & nd & nd & nd & nd & nd & nd & nd & + \\
\hline $\begin{array}{l}\text { Pigment } \\
\text { production }\end{array}$ & nd & nd & nd & nd & nd & nd & nd & nd & Red \\
\hline
\end{tabular}

+ = positive; $-=$ negative; nd $=$ no determined.

TABLE 3: Microbial production of $\mathrm{NH}_{3}$ and $\mathrm{HCN}$.

\begin{tabular}{lcc}
\hline Rhizobacteria & $\begin{array}{c}\text { Production of } \\
\mathrm{NH}_{3} \\
(\%)\end{array}$ & $\begin{array}{c}\text { Production of } \\
\mathrm{HCN} \\
(\%)\end{array}$ \\
\hline Bacillus sp. & 80 & 100 \\
Pseudomonas sp. & 77,77 & 100 \\
Serratia sp. & 100 & 100 \\
\hline
\end{tabular}

we can think there are more crops associated with maize in northern and central Benin than in southern Benin. But it is important to indicate that Adjanohoun et al. [26] had noted the crops sown in fields before maize sowing, while this study registered the crops sown in the study zone during the sampling.

The soil aerobic mesophilic microflora has greatly varied from an agroecological zone to another (Figure 2(a)), but this difference is not significant $(p>0.05)$ at probability level $5 \%$. This result can be explained by the large variability of microbial density in a same agroecological zone due to the soil heterogeneity existing in each zone. On the contrary, the density of aerobic mesophilic microflora has also greatly varied from a soil type to another, but the difference is highly significant $(p<0.001)$ at probability level 5\% (Figure 2(b)). The variability of microbial density is probably due to physicochemical properties of the different soil types, which certainly impact the microbial activity in rhizosphere. These results are similar to those obtained by Adjanohoun et al. [26] in southern Benin when they observed a large difference of microbial density between Vertisols, Degraded Bar Land, and Not Degraded Bar Land. Indeed, Schoenborn et al. [27] reported that rhizosphere contains a great microbial population between $10^{8}$ and $10^{9} \mathrm{CFU} / \mathrm{g}$ of soil. This microbial abundance is explained by the richness of rhizosphere in nutrients such as sugars, amino acids, organic acids, hormones, and other small molecules derived from root exudates [28]. The microorganisms find in rhizosphere the energy substrates required for their metabolism [29]. Conversely, in stressed ecosystem the microorganism population can be less than $10^{4} \mathrm{CFU} / \mathrm{g}$ of soil [30]. So in spite of the different environmental stress (climate change), the maize rhizosphere in central and northern Benin still contains an abundant microbial population.

The density of isolated rhizobacteria has varied according to the agroecological zone and the soil types (Figure 3 ). The density difference between the soil types is significant for Bacillus sp. $(p>0.05)$ and highly significant $(p<0.001)$ for Pseudomonas sp. and Serratia sp. The microbial density varied from 3.2 to $6.03 \times 10^{6} \mathrm{CFU} / \mathrm{g}$ of soil (Pseudomonas sp.), 1.05 to $3.33 \times 10^{6} \mathrm{CFU} / \mathrm{g}$ of soil (Bacillus sp.), and 0.67 to $3.13 \times 10^{6} \mathrm{CFU} / \mathrm{g}$ of soil (Serratia spp.). These microbial densities are inferior to those obtained by Joseph et al. [31] on chickpea (Cicer arietinum L.) in India. During their work, these authors counted about 0.5 to $2.1 \times 10^{9} \mathrm{CFU} / \mathrm{g}$ and 1.1 to $2.1 \times 10^{9} \mathrm{CFU} / \mathrm{g}$ of soil for Bacillus sp. and Pseudomonas sp., respectively. In our study, Bacillus sp. population is most abundant than Pseudomonas sp. and Serratia sp. This remark was earlier done by Saharan and Nehra [8] when they asserted that Bacillus sp. is the most abundant genus in their studied rhizosphere. In addition, Garbeva et al. [32] had concluded that a majority of soil gram positive bacteria $(95 \%)$ are member of the genus Bacillus (B. mycoides, B. pumilus, $B$. megaterium, $B$. thuringiensis, and $B$. firmus, etc.) similar to Paenibacillus.

Several rhizobacteria species were isolated, namely, $B$. polymyxa, B. pantothenticus, B. anthracis, B. thuringiensis, B. circulans, $P$. cichorii, $P$. putida, P. syringae, and Serratia marcescens (Table 2). In southern Benin, Adjanohoun et al. [26] isolated from maize rhizosphere $B$. coagulans, $B$. thuringiensis, $B$. pumilus, B. polymyxa, B. licheniformis, $B$. lentus, $B$. circulans, B. firmus, $P$. fluorescens, $P$. aeruginosa, P. putida, S. hygroscopicus, S. rimosus, S. fasciculatus, and A. lipoferum. These results still indicate the large microbial diversity of maize rhizosphere in Benin.

In order to identify Plant Growth Promoting Rhizobacteria among isolated rhizobacteria in the central and northern Benin, we have screened all the strains for ammonia and hydrogen cyanide production. Thus, all the Serratia strains followed by $80 \%$ of Bacillus and $77.77 \%$ of Pseudomonas produced ammonia. These rates of ammonia production are lower than the $95 \%$ and $94 \%$ obtained, respectively, for Bacillus sp. and Pseudomonas sp. by Joseph et al. [31]. Likewise, all Bacillus and Pseudomonas isolated by Yadav 
et al. [33] from chickpea rhizosphere in India have also produced ammonia. Ammonia production is an important characteristic of PGPR, which indirectly influences plants growth [33].

All strains produced hydrogen cyanide (100\%). Our results seem higher than the $75 \%$ of hydrogen cyanide production by Bacillus sp. strains isolated from rice rhizosphere [34] and $40 \%$ of bacteria (Bacillus sp., Pseudomonas sp., Enterobacter sp., Acinetobacter sp., and Micrococcus sp.) isolated from the beans rhizosphere [35] in India. Indeed, the hydrogen cyanide is part of powerful antifungal compounds produced by PGPR and involved in pathogens biological control [36].

\section{Conclusion}

The maize rhizospheres in central and northern Benin contain high diversity of microorganisms. The bacterial density is generally high and varies according to both the agroecological zones and the type of soils. Nine species of potentially maize plants growth promoting rhizobacteria $(B$. polymyxa, B. pantothenticus, B. anthracis, B. thuringiensis, B. circulans, P. cichorii, P putida, P. syringae, and Serratia marcescens) were identified during this study. All isolates have produced hydrogen cyanide, while $86.66 \%$ of them produced ammonia. In perspective, these rhizobacteria will be assessed to promote maize seeds germination and plant growth.

\section{Conflict of Interests}

The authors declare that there is no conflict of interests regarding the publication of this paper.

\section{Acknowledgments}

The authors acknowledge the International Foundation of Sciences (IFS research Grant no C/5252-1) and West Africa Agricultural Productivity Programme (WAAPP/PPAAO) for funding this work.

\section{References}

[1] B. R. Glick, "Plant growth-promoting bacteria: mechanisms and applications," Scientifica, vol. 2012, Article ID 963401, 15 pages, 2012.

[2] S.-Y. Koo and K.-S. Cho, "Isolation and characterization of a plant growth-promoting rhizobacterium, Serratia sp. SY5," Journal of Microbiology and Biotechnology, vol. 19, no. 11, pp. 1431-1438, 2009.

[3] P. Karuppiah and S. Rajaram, "Exploring the potential of chromium reducing Bacillus sp. and there plant growth promoting activities," Journal of Microbiology Research, vol. 1, no. 1, pp. 17-23, 2011.

[4] S. C. Wu, Z. H. Cao, Z. G. Li, K. C. Cheung, and M. H. Wong, "Effects of biofertilizer containing $\mathrm{N}$-fixer, $\mathrm{P}$ and $\mathrm{K}$ solubilizers and AM fungi on maize growth: a greenhouse trial," Geoderma, vol. 125, no. 1-2, pp. 155-166, 2005.
[5] J. W. Kloepper, M. N. Schroth, and T. D. Miller, "Effects of rhizosphere colonization by plant growth promoting rhizobacteria on potato plant development and yield," Ecology and Epidemiology, vol. 70, pp. 1078-1082, 1980.

[6] Y. Kapulnik, Y. Okon, J. Kigel, I. Nur, and Y. Henis, "Effect of temperature, nitrogen fertilization and plant age on nitrogen fixation by Setaria italica inoculated with Azospirillum brasilense (strain cd)," Plant Physiology, vol. 68, no. 2, pp. 340343, 1981.

[7] B. J. Haghighi, O. Alizadeh, and A. H. Firoozabadi, “The role of plant growth promoting rhizobacteria (PGPR) in sustainable agriculture," Advances in Environmental Biology, vol. 5, no. 10, pp. 3079-3083, 2011.

[8] B. S. Saharan and V. Nehra, "Plant growth promoting rhizobacteria: a critical review," Life Sciences and Medicine Research, vol. 21, pp. 1-30, 2011.

[9] M. Yazdani, M. A. Bahmanyar, H. Pirdashti, and M. A. Esmaili, "Effect of phosphate solubilization microorganisms (PSM) and plant growth promoting rhizobacteria (PGPR) on yield and yield components of corn (Zea mays L.)," World Academy of Science, Engineering and Technology, vol. 49, pp. 90-92, 2009.

[10] P. A. Noumavo, E. Kochoni, Y. O. Didagbé et al., "Effect of different plant growth promoting rhizobacteria on maize seed germination and seedling development," American Journal of Plant Sciences, vol. 4, no. 5, pp. 1013-1021, 2013.

[11] A. Adjanohoun, P. Noumavo, R. Sikirou et al., "Effets des rhizobactéries PGPR sur le rendement et les teneurs en macroéléments du maïs sur sol ferralitique non dégradé au Sud-Bénin," International Journal of Biological and Chemical Sciences, vol. 6, pp. 279-288, 2012.

[12] U. Chakraborty, B. N. Chakraborty, P. R. Chowdhury, C. Tongden, and M. Basnet, "Investigation on plant growth promoting rhizobacteria of tea rhizosphere," in Proceedings of the 6th International Workshop on Plant Growth Promoting Rhizobacteria (PGPR '06), pp. 78-82, IISR, Calicut, India, 2006.

[13] M. H. Abd-Alla, "Use of organic phosphorus by Rhizobium leguminosarum biovarviceae phosphatases," Biology and Fertility of Soils, vol. 18, no. 3, pp. 216-218, 1994.

[14] H. Rodríguez and R. Fraga, "Phosphate solubilizing bacteria and their role in plant growth promotion," Biotechnology Advances, vol. 17, no. 4-5, pp. 319-339, 1999.

[15] M. A. Whitelaw, T. J. Harden, and G. L. Bender, "Plant growth promotion of wheat inoculated with Penicillium radicum sp. nov.", Australian Journal of Soil Research, vol. 35, no. 2, pp. 291300, 1997.

[16] N. Vassilev, M. Toro, M. Vassileva, R. Azcon, and J. M. Barea, "Rock phosphate solubilization by immobilized cells of Enterobacter sp. in fermentation and soil conditions," Bioresource Technology, vol. 61, no. 1, pp. 29-32, 1997.

[17] M. L. Speck, Compedium of Methods for Examination of Food Microbiological, American Public Health Association, Washington, DC, USA, 1976.

[18] Y. Aparna and J. Sarada, "Molecular characterization and Phylogenetic analysis of Serratia sp-YAJS - an extracellular Dnase producer isolated from rhizosphere soil," Science Research Reporter, vol. 2, no. 1, pp. 104-109, 2012.

[19] A. T. Wahyudi, R. P. Astuti, A. Widyawati, A. Meryandini, and A. A. Nawangsih, "Characterization of Bacillus sp. strains isolated from rhizosphere of soybean plants for their use as potential plant growth for promoting rhizobacteria," Journal of Microbiology and Antimicrobials, vol. 3, pp. 34-40, 2011. 
[20] E. O. King, M. K. Ward, and D. E. Raney, “Two simple media for the demonstration of pyocyanin and fluorescein," The Journal of Laboratory and Clinical Medicine, vol. 44, pp. 301-307, 1954.

[21] J. Guiraud and P. Galzy, Lanalyse microbiologique dans les industries alimentaires, L'Usine Nouvelle, Paris, France, 1980.

[22] D. Clauss and R. C. W. Berkeley, "Genus Bacillus," in Bergey's Manual of Determinative Bacteriology, Williams \& Wilkins, Baltimore, Md, USA, 1986.

[23] F. M. Olajuyigbe and J. O. Ajele, "Production dynamics of extracellular protease from Bacillus species," African Journal of Biotechnology, vol. 4, no. 8, pp. 776-779, 2005.

[24] H. Lorck, "Production of hydrocyanic acid by bacteria," Physiologia Plantarum, vol. 1, no. 2, pp. 142-146, 1948.

[25] J. C. Cappuccino and N. Sherman, Microbiology: "A Laboratory Manual“, Benjamin/Cummings, New York, NY, USA, 1992.

[26] A. Adjanohoun, L. Baba-MouSSA, R. Kakai et al., "Caractérisation des rhizobactéries potentiellement promotrices de la croissance végétative du maïs dans différents agrosystèmes du Sud-Bénin," International Journal of Biological and Chemical Sciences, vol. 5, no. 2, pp. 433-444, 2011.

[27] L. Schoenborn, P. S. Yates, B. E. Grinton, P. Hugenholtz, and P. H. Janssen, "Liquid serial dilution is inferior to solid media for isolation of cultures representative of the phylum-level diversity of soil bacteria," Applied and Environmental Microbiology, vol. 70, no. 7, pp. 4363-4366, 2004.

[28] D. V. Badri, T. L. Weir, D. van der Lelie, and J. M. Vivanco, "Rhizosphere chemical dialogues: plant-microbe interactions," Current Opinion in Biotechnology, vol. 20, no. 6, pp. 642-650, 2009.

[29] A. Adam, Elicitation de la résistance systémique induite chez la tomate et le concombre et activation de la voie de la lipoxygénase par des rhizobactéries non-pathogènes [Thèse de Doctorat], Université de Liège, Liège, Belgium, 2008.

[30] S. Timmusk, V. Paalme, T. Pavlicek et al., "Bacterial distribution in the rhizosphere of wild barley under contrasting microclimates," PLoS ONE, vol. 6, no. 3, Article ID e17968, 2011.

[31] B. Joseph, R. Ranjan Patra, and R. Lawrence, "Characterization of plant growth promoting rhizobacteria associated with chickpea (Cicer arietinum L.)," International Journal of Plant Production, vol. 2, pp. 141-152, 2007.

[32] P. Garbeva, J. A. Van Veen, and J. D. Van Elsas, "Predominant Bacillus spp. in agricultural soil under different management regimes detected via PCR-DGGE," Microbial Ecology, vol. 45, no. 3, pp. 302-316, 2003.

[33] J. Yadav, J. P. Verma, and K. N. Tiwari, "Effect of plant growth promoting Rhizobacteria on seed germination and plant growth Chickpea (Cicer arietinum L.) under in vitro conditions," Biological Forum, vol. 2, no. 2, pp. 15-18, 2010.

[34] P. Karuppiah and S. Rajaram, "Exploring the potential of chromium reducing Bacillus sp. and there plant growth promoting activities," Journal of Microbiology Research, vol. 1, no. 1, pp. 17-23, 2011.

[35] A. Kumar, A. Kumar, S. Devi, S. Patil, C. Payal, and S. Negi, "Isolation, screening and characterization of bacteria from Rhizospheric soils for different plant growth promotion (PGP) activities: an in vitro study," Recent Research in Science and Technology, vol. 4, no. 1, pp. 1-5, 2012.

[36] D. Haas and G. Défago, "Biological control of soil-borne pathogens by fluorescent pseudomonads," Nature Reviews Microbiology, vol. 3, no. 4, pp. 307-319, 2005. 

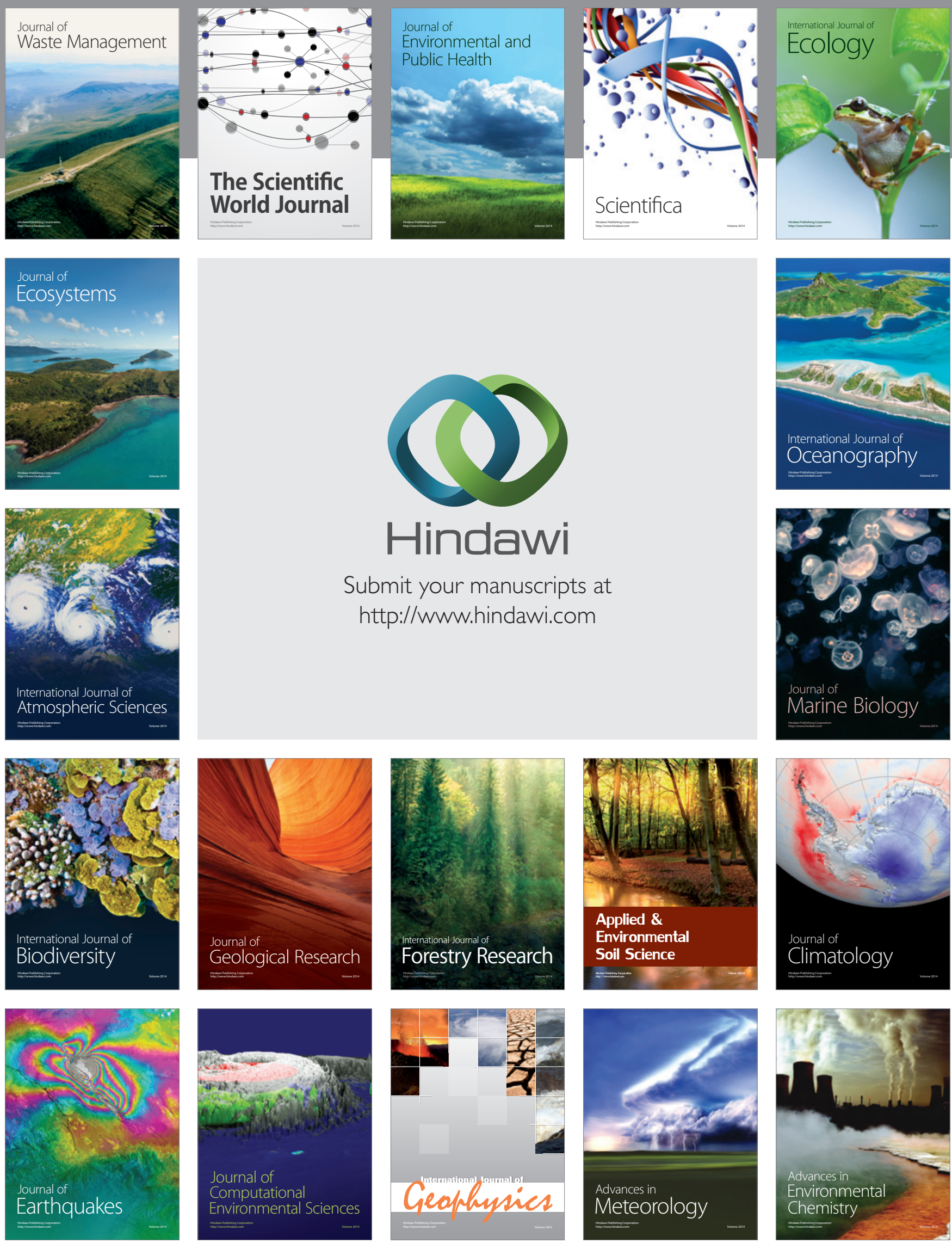